\author{
Raimundas Lopata* \\ Generolo Jono Žemaičio Lietuvos karo akademija
}

\title{
Kaliningradas Europos saugumo architektūroje po Krymo aneksijos
}

Po Rusijos agresijos prieš Ukrainą ir Krymo okupacijos nekelia abejonių Maskvos pastangos daryti ittaką galios pusiausvyrai ir Baltijos jūros regione. Šios pastangos dažniausiai yra analizuojamos post factum. Tarsi netiketai buvo prisimintas ir Rusijos potencialas tokiai įtakai, pasinaudojant Kaliningrado (Karaliaučiaus) srities veiksniu. Tai kelia įtarimų, kad akademiniuose tyrimuose kaliningradistikai, kaip geostrateginiam veiksniui, nebuvo skiriamas deramas dèmesys.

Kyla klausimų, kaip transformuojasi Rusijos Federacijos Kaliningrado (Karaliaučiaus) srities geopolitinis statusas, kokị vaidmenị Europos saugumo architektūroje šiam eksklavui numato Maskva ir ar tas vaidmuo tik regioninis? Vienas iš būdų ieškoti atsakymų - verifikuoti metropolijos taikomą sričiai valdomumo modelį, ịtikinamai pagrịstą geopolitinio įkaito koncepcija.

Maskva griežtina socialinių - socialinių, ekonominių ir politinių procesų Kaliningrado srityje kontrolę. Ji finansinemis subsidijomis, infrastruktūriniais projektais ir ịstatymiškai modifikuodama srities statusą, mègina stabilizuoti socialinę-ekonominę padètị eksklave, deda visas pastangas palaikyti Kaliningrado srities gyvybingumą izoliacijos ir tranzito varžymo (nutraukimo) sąlygomis. Politinè kontrolè užtikrinama Maskvos tiesioginiais statytiniais srities vadovybėje ir „Vieningosios Rusijos" dominavimu vadinamosiose renkamose institucijose.

Po karo prieš Gruziją, t. y. maždaug nuo 2009 m., Rusija èmèsi kryptingų žingsnių sparčiau modernizuoti ir perorganizuoti savo karines pajègas. Analizuojant Rusijos karinių pajègų vystymo priemones, taikytas Vakarų karinèje apygardoje, galima teigti, kad 2015-2016 m. Maskva igijo visišką konvencinès ginkluotės pranašumą prieš NATO. Kaliningrado srities vieta šiame procese buvo esminè. Ne tik menamai, bet ir praktiškai, šis eksklavas tapo Rusijos karinio bastiono funkcijas atliekančiu veiksniu. Strategiškai vertinant, tai prikelta naujam gyvenimui sena Kaliningrado perspektyva.

Kaliningradas tapo Rusijos A2/AD „burbulo“ centru, keliančiu iššǔkius Skandinavijos šalių, Suomijos, Baltijos valstybių, Lenkijos, ergo Vakarų Europos saugumui. Kaliningradas virto veiksniu, mažinančiu Baltarusijos geopolitinị vaidmenị. Nuosekli Kaliningrado remilitarizacija daro ịtaką ne tik regiono valstybèms, bet ir transatlantiniams santykiams. Maskvos tikslas - ir Kaliningrado veiksnys turi tapti strateginiu dialoge dèl jègų balanso su Vakarais, visų pirma su JAV. Maskva neslepia, kad lygiagrečiai su Kaliningrado sritimi Baltijos jūros regione remilitarizuojamų Tolimuosiuose Rytuose Kurilų paskirtis - mažinti geostrateginę JAV ịtaką, didinti Rusijos saugumą ir už jos sienų perimetro.

\footnotetext{
Prof. dr. (HP) Raimundas Lopata - Vilniaus universiteto Tarptautinių santykių ir politikos mokslų instituto profesorius, Adresas korespondencijai: Vokiečių g. 10, 01130 Vilnius, tel. 85251 4130, el. p.: raimundas.lopata@tspmi.vu.lt " Studija parengta Generolo Jono Žemaičio Lietuvos karo akademijos užsakymu. 2017 m. lapkričio 13 d. autorinè sutartis Nr. 8P-8.
} 


\section{Ivadas}

Po Rusijos karinès intervencijos ị Ukrainą ir Krymo okupacijos prasidèjusi galios pusiausvyros slinktis Baltijos jūros regione verčia permąstyti Rusijos Federacijos Kaliningrado srities geopolitinị statusą, jo vietą Europos saugumo architektūroje.

Verta priminti, jog problemos, ilgą laiką įvardijamos Kaliningrado galvosūkiu, ištakos ir originalumas - geopolitinès. Glaustas jų apibūdinimas būtų toks. Po Antrojo pasaulinio karo Sovietų Sajungai atitekusi Rytų Prūsijos dalis buvo paversta milžiniška sovietų karine baze. Ji atliko forposto prieš Vakarus ir barjero, padedančio SSRS užtikrinti Rytų Pabaltijo priklausomybę bei dominavimą Lenkijoje, funkcijas. Po Šaltojo karo Rusijos Federacijai priklausanti, labiausiai ị Vakarus nutolusi, beveik milijoną gyventojų turinti 15100 kvadratinių kilometrų teritorija, nors ir besiribojanti su Baltijos jūra, sausumoje buvo atskirta nuo metropolijos ir virto (pusiau) eksklavu. Palaipsniui šis eksklavas atsidūrẻ skirtingų saugumo struktūrų kryžkelèje, o vèliau - vienos iš jų - euroatlantinès - apsuptyje. Padèties pokyčiai pagimdè vadinamąjj kaliningradistikos diskursą, t. y. tarptautinès politikos Vidurio ir Rytų Europoje slinkčių, taip pat SSRS / Rusijos Federacijos vidaus transformacijos veikiamus politinius sprendimus ir akademines diskusijas bei tyrimus (R. D. Asmus, S. Browning, S. Dewar, D. Fairlie, P. Holtom, P. Joenniemi, R. Krickus, Č. Laurinavičius, R. C. Nürick, I. Oldberg, A. Sergiunin, V. Sirutavičius, I. Stanytė-Toločkienè, Ch. Welmann ir kt.) dèl šio Rusijai priklausančio eksklavo vaidmens Rytų-Vakarų santykiuose, jo vietos Rusijos užsienio ir vidaus politikoje ${ }^{1}$.

\section{Tyrimų probleminiai laukai}

Akademinèje literatūroje interpretacijų Rusijos Federacijos Kaliningrado srities tema panorama gana plati. Pastebėtina, kad tyrimų smaigalyje atsidurdavę klausimai - kaip SSRS žlugimas dare įtaką Kaliningrado sričiai, kuo ji bus ateityje, koks vaidmuo teks metropolijai ir kaimynams, koki poveiki ji patirs dèl euroatlantinès plètros ị Rytus, kaip tarptautinè bendrija turètų padèti sričiai adaptuotis prie kintančios aplinkos ir pan. - dažniausiai sutapdavo su Vakarų-Rytų santykių po Šaltojo karo slinktimis. Kadangi pastarąsias iš esmès ženklino vadinamosios naujos saugumo architektūros paieškos, Kaliningrado

\footnotetext{
${ }^{1}$ Lopata R. (2006), Rusijos Federacijos Kaliningrado srities geopolitine transformacija. Habilitacijos procedūrai teikiamų mokslo darbų apžvalga, Vilnius: Vilniaus universitetas, p. 6.
} 
tematikoje įsivyravo nesaugumo, „srityje potencialiai užkoduotos grèsmès“ ìveikos tendencija.

Jos sklaidą sąlyginai galima skirstyti $\mathfrak{i}$ tam tikrus etapus. XX a. devintojo dešimtmečio pabaigoje - dešimtojo dešimtmečio pradžioje šią tendenciją atspindejjo tekstai, modeliuojantys Kaliningrado srities ateitị Potsdamo šleifo pagrindu, taip pat nagrinëjantys srities keliamą karinę grèsmę Baltijos jūros regiono saugumui.

Maždaug XX a. dešimtojo dešimtmečio viduryje kaip alternatyva ịvairiems srities internacionalizavimo bei demilitarizavimo pasiūlymams buvo pradèta vystyti Kaliningrado - „Baltijos Hong Kongo“ - idèja. Ja méginta atskleisti srities, kaip galimo ekonominio tilto (sąsajos) tarp Rytų ir Vakarų, potencialą.

Amžių sandūroje, po praktinių žingsnių sumažinant eksklavo militarizacijos lygị, kaliningradistikoje sustiprèjo prioritetai nekarinio pobūdžio grèsmèms. Vis daugiau dèmesio susilaukè klausimai dèl Europos Sąungos plètros ¿ Rytus poveikio socialinei-ekonominei srities raidai, jos atsilikimo nuo kaimynų ir virtimo „dviguba periferija“ pasekmių. Populiariomis tapo rekomendacijos, siūliusios tokio pobūdžio problemas ịveikti tais politinès erdvès organizavimo principais, kuriais remiasi ES daugiapakope valdymo logika ir kurie yra skleidžiami ES plètros.

Pagaliau Kaliningrado sričiai atsidūrus NATO ir ES apsuptyje, kilusios itampos buvo susietos su Rusijos keleivių, prekių, karinio tranzito ị / iš Kaliningrado srities praktiniais-techniniais sprendimais².

Taigi, Kaliningrado sritis netapo tuo veiksniu, kuris užtvère kelią euroatlantinių institucijų plètrai, jis nesukèlè karinio konflikto, kaip kartais buvo prognozuojama, galų gale vadinamojo minkštojo saugumo kontekste nevirto „juodąja skyle“, socialinès-ekonominès destabilizacijos Baltijos jūros regione židiniu, apie ką taip pat buvo nemažai šneketa ir rašyta. Kitaip tariant, galima būtų teigti, jog Kaliningrado ratas juda pirmyn, skatindamas galvoti apie pažangą po kiekvieno ciklo.

Kita vertus, neišsipilde ir optimistinis scenarijus, reikalaujantis netradicinių susiklosčiusios situacijos sprendimų, brěžęs laisvos prekybos, plačios autonomijos ir aiškaus srities savaveiksmiškumo kontūrus. Akademinès diskusijos dèl to, ar šioje Baltijos jūros regiono dalyje stebimas Vakarų ir Rytų struktūrų persidengimo procesas iš esmès neutralizavo srityje „užkoduotą potencialią grèsmę“, tebevyksta. Tiesa, jos iki Rusijos agresijos prieš Ukrainą nebuvo aktyvios, o ir diskutuota senomis temomis. Kitaip tariant, tebesiaiškinama, ar eksklavas, atsižvelgiant ị jo istorinius, kultūrinius,

${ }^{2}$ Plačiau žr.: Lopata (1 išnaša), p. 13-18. 
socialinius-ekonominius, geopolitinius ypatumus, gali virsti nestabilumo židiniu, ar sritis, priešingai, turi potencialo tapti bandomuoju regionu VakarųRusijos partnerystei?

Štai prieš keletą metų Švedijos gynybos koledžo finansuotoje kolektyvinèje monografijoje „Iššūkiai krizių valdymui Kaliningrade“ aptariamos, nesibodint istorinio rakurso, srities administravimo, socialinių ir ekonominių procesų valdymo, ekologinių grèsmių problemos ${ }^{3}$.

Lenkijai ir Rusijai $2012 \mathrm{~m}$. pasirašius susitarimą dèl supaprastintų pasienio regionų gyventojų kelionių, suskubta džiaugtis teigiamam šio susitarimo pobūdžiui. Lenkai gana drąsiai kèlè tezę apie tai, jog ị rusų eksklavą jau nebežiūrima išimtinai pro karinius žiūronus, besikeičiantys NATO, ES ir Rusijos Federacijos santykiai gali daryti teigiamą itaką ir Kaliningrado vaidmeniui Lenkijos-Rusijos santykiuose. O tuometinis Lenkijos užsienio reikalų ministras R. Sikorskis dèkojo: „Ačiū rusų pirkèjams, [...] mūsų pasienio vaivadijose, patekusiose ị susitarimu apibrèžtą teritoriją, parduotuvių apyvarta išaugo $30 \%$ “4. Dékojo lenkai rusams neilgai.

Po Rusijos 2014 m. agresijos prieš Ukrainą išryškeję̨s akivaizdus Kaliningrado srities militarizacijos procesas optimizmą išsklaidè. Atgimè prieš trejetą dešimtmečių vartotos karinio forposto, bastiono, placdarmo ir pan. sąvokos 5 . Prabilta apie realų karinị konfliktą.

\section{Kaliningrado dosjẻ segmentai}

Kaliningrado dosjè - tai metropolijos (Rusijos Federacijos) santykio su nuo jos geopolitiškai atskirtu teritoriniu fragmentu (Kaliningrado sritimi) būsenos raiškos, priklausančios nuo vidinių ir tarptautinių veiksnių, pynès (kombinacijos). Daugiau nei penkiolika metų vidinių ir išorinių veiksnių kombinacijos lemia jų ịvairovę, vienaip ar kitaip keliančią Rusijai strateginio vyriausybès pajėgumo valdyti eksklavą sparčiai besikeičiančioje vidaus bei tarptautinejje aplinkoje uždavinị. Tuo metu, kai akademinè bendruomenè at-

\footnotetext{
${ }^{3}$ Krasnov E., Karpenko A., Simons G., eds. (2016), Crisis Management Challenges in Kaliningrad, London and New York: Routledge, 215 p.

${ }^{4}$ Żukowski A., Modzelewski W. T. eds. (2016), Kaliningrad: Its Internal and External Issues, Olsztyn, Institute of Political Science University of Warmia and Mazury in Olsztyn, s. 81-92, 101.

${ }^{5}$ Agee Ch. (2016), „Kaliningrad could be next flashpoint between Russia and the West“, https://www. irishtimes.com/opinion/kaliningrad-could-be-next-flashpoint-between-russia-and-the-west-1.2845352, 2016-10-27 ; Sukhankin S. “The Kaliningrad Oblast Today: A 'Military Bastion 2.0', Not a Bridge Cooperation", https://www.diplomaatia.ee/en/article/the-kaliningrad-oblast-today-a-military-bastion-20-not-abridge-of-cooperation/ 2017-06-25.
} 
kakliai tebeieško srities ateities vizijų, Maskva sprendžia kur kas pragmatiškesnius klausimus. Komplikacijas metropolijai kelia dilema tarp vaidmens, kuris, Maskvos nuomone, priklauso jai teisètai (по праву) ir vaidmens, kuri jai leidžia atlikti išorinè aplinka. Kitaip tariant, Rusija priversta koreguoti savo galimybes igyvendindama vienokią ar kitokią santykio su fragmentu strategiją, derindama ją prie kintančios aplinkos tiek srityje, tiek aplink ją. Nesėkmė sprendžiant šią dilemą atvertų realią galimybę sričiai tolti nuo Maskvos, neatmetant metropolijos defragmentacijos scenarijaus.

Metropolijoms didžiausią rūpestị kelia strateginio pajėgumo valdyti teritorinius fragmentus uždavinys. Jis reikalauja užtikrinti atskirtų regionų saugumą, tinkamą jų socialinę-ekonominę raidą, susisiekimą su jais, taip pat kryptingų pastangų formuojant teritorinès anomalijos gyventojų lojalumą centrui. Todèl metropolijos, ieškodamos būdų, kaip neutralizuoti grèsmes suverenitetui, dažniausiai siekia ịtvirtinti teritorinèse anomalijose administravimą, kuris nepažeistų vyraujančių valstybejje politinès-teritorinès kontrolès principų, deda visas pastangas užtikrinti efektyvų ryšị ir susisiekimą su juo („kaimyninès valstybès, host state ignoravimas“). Kaimyninès valstybès vaidmuo pasireiškia jos reakcijoje į metropolijos veiksmus, siekiant užtikrinti susisiekimą su eksklavu / anklavu. O pastarasis, ypač tais atvejais, kai jo ir metropolijos santykių problematika pasiekia vadinamosios „aukštosios“ politikos lygmeni, patiria „eksklavo / anklavo sindromą" - jeigu tokio pobūdžio teritoriniai dariniai vertinami kaip specifiniai ar ypatingi, tačiau konkrečiomis priemonemis nèra realizuojami specifiniai jame gyvenančiųjų poreikiai, galų gale toks teritorinis darinys „praranda" norą turèti specialų statusą. Kitaip tariant, minètame trikampyje svarbiausias vaidmuo tenka būtent metropolijai, jos strategijai ir taktikai atskirtos teritorijos atžvilgiu.

Interesas stiprinti saitus tarp metropolijos ir eksklavo determinavo Maskvos strateginę liniją paversti šią sritị geopolitiniu ịkaitu - cesijos procese kaip karo grobis atitekusia teritorija, kurią siekiama ne tik išlaikyti (vidinis aspektas), bet ir priversti kitas šalis, tarptautines institucijas ịvykdyti arba susilaikyti nuo bet kokio tiesioginio arba netiesioginio ịkaito išlaisvinimo akto (išorinis aspektas).

Praktinè šio geopolitinio ịkaito raida leidžia ịvardyti tuos Kaliningrado dosjè segmentus (veiksnius), kurie lemia metropolijos (Rusijos Federacijos) santykio su nuo jos geopolitiškai atskirto teritorinio fragmento (Kaliningrado srities) būsenas raiškas: 
- Strateginis Rusijos vyriausybės pajėgumas ir poreikis valdyti eksklavą:

- teisinès srities priklausomybès Rusijai legitimizacija;

- valdymo efektyvumas (administravimo gebejjimai, finansinè dimensija, socialinès-ekonominès modernizacijos aspektas, srities saviidentifikavimo problema);

- karinè eksklavo funkcija.

- Kitų valstybių ir tarptautinių institucijų veiksnys Kaliningrado problemoje.

- Eksklavo teritorinès jungties su metropolija užtikrinimas (karinio, keleivių ir prekių tranzito klausimai).

\section{Strateginis Rusijos vyriausybès pajègumas ir poreikis valdyti eksklavą}

Šiuo veiksniu iš esmès apibūdinama Kaliningrado srities, kaip saugumo objekto, vertẻ Rusijos Federacijai. Po Šaltojo karo eksklavinès teritorijos vertę apsprendẻ kelių priežasčių - simbolinių ir strateginių - kombinacija.

Formaliai pirmąsias atspindèjo rusų politinè retorika apie Kaliningradą / Kenigsbergą, kaip Rusijai teisètai atitekuși ir priklausantị Antrojo pasaulinio karo trofejjų. Tačiau gelminiu tokios retorikos pagrindu buvo Kaliningrado srities statuso komplikacijos tarptautinès teisès požiūriu ir su tuo tiesiogiai susijusi vadinamojo Potsdamo šleifo įveika.

Antrąsias - praktiniai Maskvos bandymai išnaudoti srities geopolitini reikšmingumą, t. y. arba išlaikyti eksklavą kaip karinị forpostą prieš Vakarus, arba paversti ji vartais, per kuriuos realizuotųsi Rusijos struktūrinis artèjimas su Vakarais, arba sukurti sąlygas jam virsti Rusijos geopolitiniu placdarmu („praeinamuoju pèstininku“) Europos Sajungoje.

Pabrèžtina, kad vienoks ar kitoks srities geopolitinio reikšmingumo praktinis igyvendinimas buvo neatsiejamas ne tik nuo Maskvos pastangų legitimizuoti Antrojo pasaulinio karo igijinį, bet ir nuo pastangų jị efektyviai valdyti, t. y. ịtvirtinti tokią institucinę bazę, kuri laiduotų politinị, teisinị bei ekonominį eksklavo stabilumą.

Dèl konkrečios Kaliningrado specifikos (Potsdamo šleifas, geopolitinè padètis, socialiniai-ekonominiai ir kt. veiksniai) Maskvai didesnę reikšmę gali turèti būtent vidinis aspektas, oficialiai pridengiamas išoriniu. Kitaip tariant, Maskva siekè (siekia) išlaikyti ir sustiprinti srities politini pavaldumą centrui, kartu ieškodama kelių jos socialinei-ekonominei modernizacijai, neleidžiančiai šiuo lygmeniu eksklavui dramatiškai atsilikti nuo kaimyninių valstybių, taip pat 
būdų išnaudoti sritị kaip tam tikrą diplomatinị ịrankị tarptautinèje politikoje.

Toks Rusijos politikos modelis eksklavo atžvilgiu vertintinas kaip adekvatus raktas Kaliningrado galvosūkiui spręsti ${ }^{6}$. Jis leidžia ịveikti moksliniuose kaliningradistikos tyrimuose išryškejjusį paradoksą - Kaliningrado problemos kompleksas užfiksuotas, tačiau Kaliningrado galvosūkis tebelieka neišspręstas.

Formaliai išorinę îkaito mechanizmo sklaidą iliustravo Maskvos palaikomas žaismas dèl dviejų metropolijos strategijų eksklavo atžvilgiu. Pirmoji srities, kaip karinio Rusijos forposto, ypatingo strateginio regiono, atsižvelgiant i aplinkybes, atliekančio placdarmo ịtakai plèsti ir (arba) barjero Vakaru ittakai stabdyti vaidmenị. Antroji srities, kaip ekonominių reformų bandymų aikštelès („bandomojo regiono“), galëjusio dèl savo palankios geografinès padèties tapti geopolitine sąsaja, jungiančia Rusiją su Vakarais ir lengvinančia ūkinius, žmonių ir idèjų mainus. Tačiau realioje diplomatinëje praktikoje sritis virto savotišku įkeistu daiktu, naudojamu Rusijos ir Vakarų strateginiuose mainuose, paremt-uose atgrasinimo (sulaikymo) - nuraminimo ir susiejamumo (engagement) taktika. Paprastai kalbant, kuo mažiau NATO ir JAV dalyvavimo regione, tuo mažiau karinio rusų arsenalo srityje ir daugiau jos atvirumo ES plètros bei europinès integracijos procesams. Tačiau tokia rusiškoji frazeologija ne tik nereiškè, kad Rusija atsisako naudoti sritị kaip veiksnị spaudžiant ir šantažuojant Lietuvą, o kai kuriais laikotarpiais ir Lenkiją, bet priešingai, naudojasi ja tokių veiksmų legitimacijai. Vadinamojo rusiškojo tranzito - karinio, keleivių ir krovinių - peripetijos bene akivaizdžiausi tokio teiginio įrodymai ${ }^{7}$.

Formaliai vidinę ikkaito mechanizmo sklaidą demonstravo vadinamųjų metropolijos ịsipareigojimų sričiai likimas. Nuo pat SSRS iširimo, kai Kaliningrado sritis tapo eksklavu, ji iš centro sulaukdavo nemažai įsipareigojimų ar ịpareigojančių pažadų. Tačiau svarbiausieji buvo trys. Federalinis centras skelbè užtikrinsiąs srityje Rusijos teisinį legitimumą, efektyvų valdymą ir stabilią teritorinès jungties su metropolija (heartlandu) netekusio regiono raidą. Maskva buvo įsitikinusi, jog savo arsenale turi užtektinai vidinių išteklių bei instrumentų, taip pat pajègi išnaudoti ir išorinius veiksnius šiems įsipareigojimams igyvendinti. Todèl ji nesibodèjo teikti sričiai vilčių kaip kompensaciją už eksklaviškumą gauti naują politinį ir specifinį ekonominị statusą (Laisvoji ekonominé zona - LEZ, Ypatingoji ekonominė zona - YEZ), faktiškai neturèdama strateginio plano, kaip užtikrinti stabilią srities raidą, ir ne iš karto suvokdama tarptautinių procesų, pirmiausia - euroatlantinès integracijos masto ir spartos.

\footnotetext{
${ }^{6}$ Lopata R. (2006), Ikaito anatomija. Kaliningrado jubiliejaus byla, Vilnius: Eugrimas, p. 20-22.

${ }^{7}$ Laurinavičius Č., Lopata R., Sirutavičius V. Military Transit of the Russian Federation through the Territory of the Republic of Lithuania. Rusijos Federacijos karinis tranzitas per Lietuvos Respublikos teritorija, Vilnius: Eugrimas, $79 \mathrm{p}$.
} 
Būtent todèl formaliai metropolija neprieštaravo ir netgi skatino šią provinciją traktuoti kaip specifini regioną. Tačiau iš tikrųjų neleido tam ypatingumui reikštis. Tokiu būdu buvo siekiama sužadinti ir palaikyti srityje savotišką Stokholmo sindromą - kaliningradiečiai patys turi susitaikyti su iprasto Rusijos regiono statusu, t. y. visus sprendimus dèl srities raiškos priims Maskva, o sričiai nebus leista reikštis kaip subjektui.

\subsection{Teisinès srities priklausomybès Rusijai legitimizacija}

Po Sovietų Sąjungos žlugimo eksklavinè Kaliningrado srities padètis pagimdè specifinių politinių, ekonominių ir psichologinių ittampų. Ypač situaciją komplikavo tai, kad geopolitinès permainos sukèlè debatus ne tik dèl unikalaus valstybès fragmento pobūdžio, bet ir dèl jo tarptautinio pripažinimo Rusijai statuso.

Pastaruoju atveju aiškinta, kad Kaliningrado srities sąsajos su Rusija turi istoriškai apibrěžtą ribotą kontekstą. Faktiškai buvusi Rytų Prūsija su Kenigsbergu atiteko Sovietų Sąjungai po Antrojo pasaulinio karo kaip priemoné, užtikrinanti Rytų Pabaltijo priklausomybę Sovietų Sąjungai. Jokių istorinių teisių ị šią teritoriją Maskva neturejjo. Kitaip tariant, buvo keliama mintis, kad Kaliningrado srities klausimas neatsiejamas nuo politinès srities ateities problemos, nes juridinė krašto priklausomybè Rusijos Federacijai yra negalutinè ir terminuota (suvereno nèra, nes Potsdamo konferencijoje Rytprūsių dalis buvo priskirta laikinam SSRS administravimui iki būsimo taikos sureguliavimo).

Šiuos aiškinimus po "geležinès uždangos" griuvimo atspindejo Vakaruose ir kaimyninèse valstybèse pasirodę ịvairūs srities internacionalizavimo (padalinimų, kondominiumų, eksteriatorialumo, dekolonizacijos, autonomizacijos, nepriklausomybès ir pan.) planai.

Kita vertus, debatus lydejjo ir sąmoningos Maskvos pastangos inicijuoti ir kaitinti tokio pobūdžio diskusijas. Europos valstybès buvo išprovokuotos oficialiai atsiriboti nuo internacionalizavimo planų. Kaimyninès (tarpinès) valstybès, pirmiausia - Lietuva, pasirašè sutartis ir susitarimus dèl garantijų užtikrinti sąlygas Kaliningrado srities gyvybingumui (rus. - žizneobespečenije) laiduoti, kartu fiksuojant metropolijos „ypatingą suinteresuotumą“ eksklavo raida. Tokiu būdu metropolija siekè ịtvirtinti politinị argumentą dèl organinio srities ryšio su kontinentine Rusija, o srities politinès ateities problemą pakeisti „techniniais" regiono ekonominès ir socialinès plètros klausimais.

Rusija griežtai reaguoja ị bet kokius bandymus kvestionuoti teisinę Kaliningrado priklausomybę. 
2017 m. sausio pabaigoje parlamentaras Linas Balsys paragino peržiūrèti Kaliningrado srities (KS) statusą, reaguojant ị Rusijos įvykdytą Krymo aneksiją. Oficiali ir neoficiali Maskvos reakcija buvo tokia perdèta, kad Lietuvos užsienio reikalų ministerija suskubo pareikšti, kad ši sritis yra integrali Rusijos Federacijos dalis, „tačiau Lietuva ir toliau nepripažins vienašališkų sienų pakeitimų, kaip ir nepripažins ir Rusijos ịvykdytos Krymo okupacijos bei aneksijos" ${ }^{\text {"8 }}$. Oficialiajam Vilniui gerai žinoma ne tik, kaip Rusija reaguoja i panašius pasiūlymus, bet ir kaip ji juos inicijuoja. Štai keli pavyzdžiai.

Apie iniciaciją. 2013-2014 m. sandūroje kilus Maidano ịvykiams Kijeve, Kaliningrado gubernatorius Nikolajus Ciukanovas garsiai pareiškė, kad „Vakarų slaptosios tarnybos Lenkijos ir Lietuvos rankomis siekia srityje ižiebti kitą Maidaną" ". Vakarai atsiribojo.

Apie reakcijas. 2016 m. rugsejo pradžioje V. Putinas, duodamas išskirtinị interviu vyriausiajam „Bloomberg" redaktoriui Johnui Mickletwait, ị juokais užduotą klausimą, gal Rusija atiduotų Kaliningrado sriti, piktai atsakè: „Na, o aš jums pasakysiu visai rimtai. Jei kam nors norisi peržiūrèti Antrojo pasaulinio karo rezultatus, pabandykime padiskutuoti šia tema. Bet tada reikia kalbėti ne apie Kaliningradą, o apskritai apie rytines Vokietijos žemes, apie Lvovą, priklausiusį Lenkijai ir taip toliau“, - atsakè V. Putinas. „Dar yra ir Vengrija, ir Rumunija. Jei kas nori atverti „Pandoros skrynią“ ir pradèti su ja dirbti - prašom, pradèkite“, - pareiške Rusijos vadovas ${ }^{10}$.

Beje, šiame interviu V. Putinas pabrèžè ir tai, kad neprekiaus ir Kurilu salomis. Jis neįžvelgè Kurilų byloje jokių paralelių su Rusijos-Kinijos pasienio ginču dèl 174 kv. km. teritorijos, kurią Maskva 2005 m. atidavė Pekinui. Pasak Rusijos vadovo, rusų-kinų santykiuose vyrauja aukščiausio lygio pasitikejjimas, kurio kol kas su japonais nèra ${ }^{11}$.

Pabrèžtina, kad Kaliningrado srities ateities klausimą Maskva siejo (sieja) ne tik su Potsdamo šleifo įveika santykiuose su Vakarais, bet ir su Kurilų priklausomybės klausimo byla santykiuose su Japonija, o plačiau - šios bylos itaka Rusijos strategijai su Tolimaisiais Rytais apskritai.

\footnotetext{
${ }^{8}$ URM sureagavo ị L. Balsio pareiškimus: „Lietuva nekelia klausimų dèl Rusijos Kaliningrado srities statuso", delfi.lt, 2017 m. sausio 30 d.; Goble P. (2017), "Is Kaliningrad on Its Way to Becoming "Russia’s Crimea?”, https://jamestown.org/program/kaliningrad-way-becoming-russias-crimea/ , 2018-02-22.

${ }^{9}$ Sukhankin S. (2016), „Kaliningrad: Russia's Stagnant Enclave“, http://www.ecfr.eu/article/commentary_ kaliningrad_russias_stagnant_enclave_6052, 2017-06-24.

${ }^{10}$ „V. Putinas ịspejjo dèl svarstymų apie Antrajit pasaulinị karą“ (2016),/ https://pasaulis.lrytas.lt/ivykiai/vputinas-ispejo-del-svarstymu-apie-antraji-pasaulini-kara.htm , 2017-10-25; "We do not trade territories': Putin on Kuril Islands compromise with Japan" (2016), https://www.rt.com/news/357970-putin-japanbloomberg-interview, 2017-11-02.

${ }^{11}$ „We do not trade territories’: Putin on Kuril Islands compromise with Japan“ (10 išnaša).
} 
Kitaip tariant, Rusija suvokia, kad absoliutus teritorinis legitimumas yra nepasiekiamas tiek Kuriluose, tiek galbūt mažesniu laipsniu Kaliningrado srityje. Maskva tikisi spręsti šią problemą palankaus sau balanso sukūrimu: rytinių sienų legitimumo kvestionavimą iš Japonijos (JAV) pusės ji bando atsverti kinų korta, o Kaliningrado srities priklausomybę - Vakarų Europos valstybių korta $^{12}$. Beje, tokiu balansavimu Kremlius tikisi ne tik išlaikyti status quo vakariniame ir rytiniame flanguose, bet ir neuždaryti kelio savo eventualiems politiniams, diplomatiniams, ịtakos sferų, neatmetant teritorinių, laimèjimams.

\subsection{Valdymo efektyvumas}

Bandymai galios pusiausvyros kombinacijomis neutralizuoti srities statuso kontroversiškumą tarptautinès teisès požiūriu turèjo ir turi tiesioginę ittaką Maskvos pozicijai dèl praktinès eksklavo valdymo raiškos.

Kremlius stengėsi sukurti galimo savaveiksmio Rusijos Federacijos subjekto - Kaliningrado srities - įvaizdį. Tiesa, tokio įvaizdžio praktinès raiškos formos itvairavo.

Kaliningrado srities raidos trajektorija po $1991 \mathrm{~m}$. atrodè gana optimistiška. Gubernatoriumi tapo progresyvus, liberaliai nusiteikęs Jurijus Matočkinas (1991-1996 m.), i̊steigta Laisvoji ekonominès zona "Jantar“ („Gintaras"), sritis - Europoje, nemažos Rusijos valdančiojo elito dalies palankumas bendradarbiavimui su Vakarais. Visa tai suteike peno viltims, kad netrukus Kaliningradas taps Rusijos vartais ị Europą, Baltijos Hong Kongu ir net ketvirtaja Baltijos valstybe. Viltys buvo sustiprintos ịvairiomis europietiškais pinigais paremtomis iniciatyvomis, turejusiomis skatinti regiono socialinį-ekonominị vystymąsi.

Viltys ir iniciatyvos rezultatų nedavè. Apie Kaliningradą netrukus pradèta kalbèti kaip apie ,juodąją skylę“, „dvigubą periferiją“, kurioje klesti korupcija, nusikalstamumas, alkoholizmas, AIDS ir pan.

Gubernatoriaus Leonido Gorbenkos laikais (1996-2000 m.) buvo ịkurta Ypatingoji ekonominè zona, virtusi kontrabandos zona. $1998 \mathrm{~m}$. finansinè krizè Rusijoje faktiškai sukèlè srityje ekonominę griūtị.

Gubernatorius, buvęs Rusijos Baltijos karinio laivyno vadas, admirolas Vladimiras Jegorovas (2000-2005 m.) bandè išeities ieškoti Specialiosios ekonominès zonos įstatymu ir Kaliningrado kaip „bandomojo regiono“ Rusijos-Europos Sajungos santykiuose ideja, sustiprinta finansinèmis „Euroregionų“ ir Šiaurès dimensijos iniciatyvų paskatomis orientuoti sritị nuo planinès prie

\footnotetext{
${ }^{12}$ Lopata (1 išnaša), p. 20.
} 
rinkos ekonomikos. Tai stabilizavo srities socialinį-ekonominị atsilikimą nuo kaimyninių valstybių, tačiau proveržio perspektyvos nenubrèžè.

Šios peripetijos atskleidè Rusijos (Maskvos) strateginę liniją imituojant galimą srities savaveiksmiškumą ịtikinti vietinị politinị elitą, jog federalinis centras turi srities raidos planą, kontroliuoja vidinius ir išorinius jo igyvendinimo svertus.

Siekdamas sritị išlaikyti, o vèliau taip pat panaudoti ją kaip priemonę, veikiančią eurointegracijos procesus, Kremlius rinkosi tik tuos būdus ir sprendimus, kurie užtikrintų pasirinktos strategijos iggvendinimą, nepaisant, kiek jie atitiko ar prieštaravo gyvybiniams srities interesams.

Kita vertus, federalinis centras savo veiksmais legitimacijai užtikrinti buvo priverstas atsižvelgti ir i j jų praktinę pusę - nededant pastangų stimuliuoti specifineje padètyje atsidūrusios srities raidą, joje gali sustiprèti antifederalinès nuotaikos. Todèl valstybiniuose dokumentuose nuolat buvo pabrežiamas tikslas užtikrinti srities, kaip neatskiriamos Rusijos Federacijos dalies, raidą, o federalinis centras nuolatos stengési su vietos politikais spręsti srities problemas. Tokiu būdu buvo mėginama švelninti tą aplinkybę, kad metropolijos nuolatinis dèmesys provincijai sutapdavo su vieno ar kito strateginio Maskvai klausimo sprendimu. Ši teigini iliustruotų tiek peripetijos, susijusios su specifinio ekonominio režimo srityje likimu, tiek srities karinio isteblišmento vaidmens raiška, tiek vadinamojo rusiško tranzito klausimai.

Maždaug 2004-2005 m., artejant vadinamajam Kaliningrado jubiliejui, Kenigsbergo miesto ịkūrimo 750-osioms metinèms, Rusija èmèsi modifikuoti geopolitinio ịkaito modelị. Aiškejjo, jog pastarasis iš esmès veda ị pato situaciją, neleidžiančią atsakyti i principinius klausimus - o kas toliau, ką duos lěšų pumpavimas ir laikymas už pavadžio svetimoje aplinkoje atidūrusio krašto?

Praejjusio dešimtmečio patirtis rodè, kad Kaliningrado klausimas pats savaime neišsispręs, metropolijai nesuradus naujų veiksnių ir naujų veikimo erdvių. Kadangi Vakarai, tarp jų Lietuva ir Lenkija, dažniausiai tik konjunktūriškai, daugiausia dèl to, kad neturi tam tradicijų bei igūdžių, demonstravo turinčios kokybes perimti regione iniciatyvą iš nusilpusios po SSRS Rusijos. Šiame kontekste būtų galima tvirtinti, jog minèto Kaliningrado / Kenigsbergo jubiliejaus peripetijos liudijo, kad Kremlius tuos naujus veiksnius bei naujas erdves surado.

Apsisprendimas ịveikti barjerą - sulaužyti sovietinę tradiciją traktuoti miesto istoriją tik nuo $1945 \mathrm{~m}$. ir pripažinti istorijos tęstinumą buvo reikšmingas Maskvos signalas Vakarams. Signalas sulauke atsako iš Vakarų, konkrečiai iš paties svarbiausio šiuo aspektu kontrahento - Berlyno. Pabrežtina, kad tai 
nebuvo vien simboliniai gestai, kurių netrūko ir anksčiau. Dabar išryškejjo ir labai konkrečios strateginio bendradarbiavimo tarp Rusijos ir Vakarų kryptys. Viena iš tų krypčių - Šiaurès Europos dujotiekis per Baltijos jūrą - netrukus pasidarè matoma visiems ${ }^{13}$.

Neatsitiktinai tuo pačiu metu naujuoju srities gubernatoriumi buvo paskirtas Georgijus Boosas - energijos, ambicijų nestokojantis ir laisvas nuo stereotipu politikas iš metropolijos. Jis ne tik prabilo apie forpostini srities vaidmenį Rusijos-Vakarų suartejjime, Kaliningrado kaip „mini-valstybès“ planus, bet ir ėmèsi, palaimintas Kremliaus, praktinių žingsnių ruošti eksklavą šiam vaidmeniui. Šią rolę pats G. Boosas apibūdino kaip „Rusijos langą i Europąa" ${ }^{14}$. Pasak jo, Kaliningrado sritis turi būti ne teritorija, kurią europiečiai stengiasi išnaudoti kaip lengvatinę kortą skverbdamiesi į Rusijos rinkas, o placdarmu rusiškajam verslui integruotis $\mathfrak{i}$ europines ir pasaulines rinkas. Todèl reikia sritị skubiai modernizuoti, t. y. sukurti skaidrią ir suprantamą finansinę sistemą, padaryti viešą biudžetini procesą, padvigubinti energetinius srities pajègumus, išvystyti transporto infrastruktūrą ir logistiką, pagaliau paruošti Specialiosios ekonominès zonos (SEZ) įstatymą taip, kad visos šios priemonès skatintų stambaus ir konkurencingo rusiškojo kapitalo atejjimą $\mathfrak{i}$ sriț $^{15}$. G. Boosas tikèjosi igyvendinti savo planus ịveikdamas korupciją, sukurdamas kitą, jo manymu, skaidresnę motyvacijų (privilegijų) sistemą ir stiprindamas ypatingu vadintą Kaliningrado tapatybės rusiškajji aspektą.

Vien pastarojo aspekto konkretus kẻlimas, siejant ji su eventualia rusų iš heartlando bei rusakalbių iš Baltijos šalių emigracija ị eksklavą, bylojo ir apie mėginimą pajudinti iš mirties taško rusakalbių klausimą Baltijos valstybėse. Nors siekis išlaikyti ịtaką Baltijos šalyse naudojantis rusakalbių korta išliko, tačiau tuo metu vykstant Rusijos ir Vakarų suartejimui bandyta neteikti jam pirmenybès. Manyta, kad Kaliningrado veiksnys turi šansų tapti „praeinamuoju pèstininku“ sudètingoje ES ir Rusijos geopolitineje šachmatų partijoje. Natūralaus ir atviro suartèjimo sąlygomis tai būtų stiprinę krašto gyventojų europeizavimo tendencijas, galinčias sukelti Rusijai nepageidaujamų politinių padarinių. Todèl tokioje situacijoje ir ieškota būdų, kaip stiprinti krašto gyventojų lojalumą Rusijai.

Pirmuosius keletą metų buvo iliuzijų dèl ekonomikos augimo. Tačiau netrukus paaiškejjo, kad SEZ ịstatymas kerta sunkiai pakeliamą smūgị smulkiajam ir vidutiniam verslui, ignoruoja užsienio investuotojus. Iliuzijas sukèlęs

\footnotetext{
${ }^{13}$ Lopata (6 išnaša), p. 128-129.

${ }^{14}$ Lopata R. (2005), „Kaliningrad Anniversary: the First Steps of Georgy Boss“, Lithuanian Foreign Policy Review, 1-2 (15-16), p. 127-152.

${ }^{15}$ Lopata (14 išnaša); Sukhankin $S$. (5 išnaša).
} 
europietiškų prekių reimportas ị metropoliją dèl 2008 m. pasaulinès krizė nutrūko. Kaliningrado sritis buvo pajungta visiškai Maskvos kontrolei, t. y. regiono ekonomika pasidare iš esmès priklausoma nuo metropolijos finansinių dotacijų.

Kilus pasaulinei ekonominei krizei paaiškèjo, kad federalinis centras neišgali subsidijuoti srities kaip iki krizès. Maskvai pareikalavus ieškoti nauju „vidaus išteklių“, G. Boosas nutare didinti mokesčius (pvz., prekybai naudotais automobiliais - populiariausiai smulkiojo verslo rūšiai), sumažinti išlaidas sveikatos apsaugai ir pan. Tai sukèlè kaliningradiečių nepasitenkinimą. 20092010 m. kilę masiniai protestai buvo pavadinti „Oranžiniu pavasariu“. Sąsaja su ukrainiečių „Oranžine revoliucija“ suteikè peno kalboms apie bręstančią Kaliningrade demokratų pergalę ir Kaliningradą kaip Rusijos Gdanską ${ }^{16}$. Tokios kalbos buvo per ankstyvos.

Kaliningradiečių protestus sukèlè ne tiek politiniai-vertybiniai ịsitikinimai, o pragmatiniai-ekonominiai motyvai ${ }^{17}$. Protestai kilo dèl to, kad Maskva nesugebèjo igyvendinti savo pažadų subsidijuoti Kaliningradą. Maskva sureagavo - ne ji kalta. Srities vadovybė buvo pakeista, mokesčiai atšaukti, subsidijos srities "gyvybingumui“ palaikyti - išskirtos. Situacija stabilizavosi, tačiau laikinai.

Vakarų sankcijos Rusijai po Krymo okupacijos palietè ir Kaliningrado sritị. Stagnuojančiai socialinei-ekonominei raidai ịtaką dare ir $2016 \mathrm{~m}$. balandžio 1 d. pasibaigęs Specialiosios ekonominès zonos statuso galiojimas. Tai palietė beveik 800 srities verslo kompanijų, kurios užtikrino darbo vietas ketvirtadaliui kaliningradiečių. Tiesa, Maskva suskubo išskirti 66 milijardus rublių kaip kompensaciją už SEZ statuso netektị, taip pat žadejjo paruošti naują įstatymą dèl Kaliningrado srities ekonominio-socialinio vystymosi ${ }^{18}$. To užteko, kad 2016 m. rugsèjo 18 d. srityje vykusiuose rinkimuose į Valstybès Dūmą, Kaliningrado srities Dūmą ir savivaldybių tarybas partija „Jedinaja Rosija“ („Vieningoji Rusija“) užsitikrintų triuškinamą pergalę, nors opozicijos atstovai prieš rinkimus ir prognozavo, kad „Jedinaja Rosija“ nesugebès surinkti daugiau nei 50 proc. balsų. İ Kaliningrado srities 40 -ies narių Dūmą buvo išrinkti 27 valdančiosios partijos nariai ${ }^{19}$. Jie turi kvalifikuotą daugumą. Vadinamoji nesisteminè, nepriklausoma opozicija iškovojo tik vieną mandatą. Bet ir jị laimëjęs „Naujųjų ratų" vyriausiasis redaktorius I. Rudnikov 2017 m. buvo sulaikytas, iškèlus jam baudžiamąją bylą dèl prievartavimo duoti kyšì.

\footnotetext{
${ }^{16}$ Sukhankin S. (2017), “Baltic Hong Kong No Longer”, https://www.fpri.org/article/2017/04/kaliningradbaltic-hong-kong-no-longer/, 2017-05-02.

${ }^{17}$ Sukhankin S. (9 išnaša).

${ }^{18}$ Sukhankin S. (9 išnaša).

${ }_{19}^{19}$ „Vybory 2016 (2016), „Dvornik“, 2016-09-27, No. 37 (1043), http://pressa-online.com/ ws.aspx?service=issue-file-download\&iid=193814, 2017-11-09.
} 
Naująj ịstatymą dèl Kaliningrado srities ekonominio-socialinio vystymosi V. Putinas pasirašè $2017 \mathrm{~m}$. gruodžio $5 \mathrm{~d}^{20}$ Jis ìsigaliojo nuo $2018 \mathrm{~m}$. sausio $1 \mathrm{~d}$. Šiuo ístatymu numatytos naujos papildomos lengvatos SEZ rezidentams: socialinio draudimo mokesčių sumažinimas, investicijų minimalios ribos sumažinimas IT ir medicinos sektoriuose, supaprastinta vizų išdavimo užsieniečiams procedūra, praplèsta SEZ teritorija, įtraukiant ị ją Kaliningrado srities vidaus vandenis ir Rusijai priklausančios Baltijos jūros dalị.

Vargu ar reikia aiškinti, kaip Kaliningrado srities rinkejjai balsavo $2018 \mathrm{~m}$. kovo mèn. Rusijos Federacijos prezidento rinkimuose. Iškalbinga, kad prieš pat rinkimus regioną aplankẻ V. Putinas ${ }^{21}$. Jis iškilmingai atidarè dvi šilumines elektrines ir pareiškè, kad tai pirmas rimtas žingsnis užtikrinant energetini Kaliningrado saugumą. O po to regiono žiniasklaidos forume jis gyrè strateginès paskirties raketų komplekso „Avangard“ kūrejus. Sakoma, kad kažkas iš ceremonijos dalyvių prisiminė patriarcho Kirilo žodžius, prieš trejetą metų ištartus Kaliningrade, esą sritis - tai „Rusų pasaulio“ Europoje švyturys ir citadelè.

\subsection{Karinè eksklavo funkcija}

Šiandien kaliningradistikoje tai - vyraujanti tema. Dažnai klausiama, kaip atsitiko, kad Kaliningrado sritis „sugrįžo i i Sovietų Sąjungos laikus ir virto kariniu bastionu, rusų $\mathrm{A} 2 / \mathrm{AD}$ „burbulu“, bene labiausiai militarizuotu regionu Europoje?

Tai neatsitiko per nakti. Per vieną naktį buvo tik pakeista visa Rusijos Baltijos karinio jūrų laivyno vadovybè.

Formaliai karinès funkcijos paskirtis - sustiprinti Kaliningrado srities priklausomybès Rusijos Federacijai garantavimą tiek vidiniu, tiek išoriniu aspektais.

Kalbant apie vidinị aspektą, ir prieš tai buvęs išlikęs srities militarizacijos laipsnis padejo Maskvai kontroliuoti srities politinio elito elgesị.

Pavyzdžiui, 1994-1995 m. Laisvosios ekonominès zonos režimo srityje apribojimą ir panaikinimą lydèjo specialaus, Rusijos Baltijos karinio laivyno vado vadovaujamo gynybinio rajono, tiesiogiai pavaldaus Gynybos ministerijai ir Generaliniam štabui, įsteigimas.

Kaliningrado srities gubernatoriaus rinkimuose $2000 \mathrm{~m}$. Kremlius iš esmès atvirai paremè tarp vietos politinio elito populiarų, tačiau asmeniškai

\footnotetext{
${ }^{20}$ Administracija Prezidenta RF // http://www.kremlin.ru/acts/news/56303, 2018-02-04.

${ }^{21}$ Выползов А. (2018), „Панихида по энергоблокаде и агрессии Литвы: Путин в Калининграде“, https://regnum.ru/news/polit/2386788.html , 20180303.
} 
V. Putinui lojalų Rusijos Baltijos karinio laivyno vadą admirolą V. Jegorovą (beje, tai buvo pirmas ir kol kas vienintelis admirolas-gubernatorius Rusijos Federacijos istorijoje).

2005 m. pabaigoje Baltijos karinio laivyno vadovybė su admirolu V. Valujevu priešakyje nedviprasmiškai perspejjo naująji gubernatorių G. Boosą, kad srities karinis elitas neigiamai vertina pastangas stiprinti srities ekonomini ir kultūrinị bendradarbiavimą su užsienio valstybėmis, esą sukuriantị sąlygas neprievartiniam Kaliningrado srities atskyrimui nuo Rusijos Federacijos.

Tuo tarpu vertinant išoriniu aspektu - srities karinis potencialas buvo Kremliaus priemoné dialoge su Vakarų Europa (JAV) dèl jègų balanso palaikymo. Šia prasme rusiškojo karinio veiksnio tramdomoji funkcija eventualiai peržengia srities ribas, kaip minimum apimdama Rytų Pabaltiji. Pavyzdžiui, 1993-1995 m. ir 2001 m. pavasarị Maskva stengèsi išnaudoti Rusijos karinio tranzito $i$ / iš Kaliningrado srities per Lietuvos teritoriją klausimą, siekdama ne tik stabdyti Lietuvos integracijos ị NATO procesą reikalaujamomis šį tranzitą ịteisinti politinėmis sutartimis, tikẻdamasi išlaikyti Lietuvą savo ịtakos zonoje, bet ir kontroliuoti apskritai Vakarų struktūrų pletros ị Rytus procesą, kartu darant įtaką geopolitinei situacijai Vidurio Rytų Europoje ${ }^{22}$. Pažymètina, kad minètais laikotarpiais Prancūzija, o ypač Vokietija, simptomiškai užimdavo nesikišimo ir net palankumo Rusijai poziciją šiu tendencijų atžvilgiu.

2001 m. pradžioje dienraščiai „The Washington Times“ ir „Daily Telegraph“ pranešè, kad rusai Kaliningrade dislokuoja taktinius branduolinius ginklus. Maskva pranešimus piktai paneigè, nors vienas ịtakingas to meto Kaliningrado politikas žaismingai pajuokavo: o kam dislokuoti, jeigu tie ginklai niekada nebuvo išvežti.

Panašu, kad pranešimais buvo mėginama pasauliui priminti, kad dar 1999 m. birželị Kaliningrado srityje vykusių karinių pratybų „Zapad-99“ metu buvo imituotas vadinamasis deeskalacijos scenarijus. Jis numate taktinio branduolinio ginklo panaudojimą NATO konvencinès ginkluotès pranašumui iveikti. Tai buvo detalizuota ir naujai patvirtintoje Rusijos nacionalinio saugumo koncepcijoje bei karinèje doktrinoje. O britai šiame kontekste paskelbẻ apie neva sudarytus slaptus Rusijos ir Vokietijos susitarimus Kaliningrado sąskaita $^{23}$. Tai sukèlè daug triukšmo ir dar daugiau interpretacijų. Tačiau ị jas ši kartą Maskva reagavo pabrežtinai ramiai. Regis, jos tik paglostė Rusijos supervalstybišką savimeilę, leidžiančią vienašališkai lemti ir Baltijos regiono likimą.

\footnotetext{
${ }^{22}$ Laurinavičius Č., Lopata R., Sirutavičius V. (2002), „Rusijos Federacijos karinis tranzitas ị / iš Kaliningrado srities per Lietuvos teritoriją", Politologija, 4, p. 3-35.

${ }^{23}$ Sirutavičius V. (2002), „Maskvos eksperimentas virsta ant kaklo veržiama kilpa“ žr.: Lopata R.,

Laurinavičius M., sudar., Tarptautine politika: komentarai ir interpretacijos, Vilnius: Eugrimas, p. 256.
} 
Pagaliau 2007 m. vasario mèn. pasaulį sudrebino V. Putino kalba „Rusija pasaulio politikoje“, pasakyta Miunchene vykusioje saugumo konferencijoje. Joje Rusijos vadovas negailèjo kritikos JAV ir Vakarams, NATO plètrai ir pabrèžè, kad Maskva pasirengusi Kaliningrado veiksnį naudoti prieš NATO ${ }^{24}$. Tai buvo tik preliudija.

Po karo prieš Gruziją, maždaug nuo 2009 m. Rusija èmėsi rimtų organizacinių ir karinių pajègų telkimo priemonių. Jos palietė ir Kaliningrado sritį, kuri jau iki $2016 \mathrm{~m}$. virto grèsmingu kariniu bastionu.

Visų pirma Kaliningrado veiksnys buvo naudojamas Maskvos vadinamojoje „Iskander diplomatijoje“, bauginant ar laikinai dislokuojant mobiliąsias balistines „Iskander“ raketas. Štai 2016-ųjų spalị Rusijos gynybos ministerija pareiškè, kad dèl ginkluotụjų pajegų kovinio parengimo Kaliningrado srityje ne kartą buvo dislokuoti raketų pajėgų daliniai su kompleksais „Iskander“ ir kad tokios praktikos atsisakyti nežadama ${ }^{25} .2018 \mathrm{~m}$. vasario viduryje apie mažo nuotolio raketų „Iskander“ dislokavimą Karaliaučiaus krašte pranešè Lietuvos Prezidente Dalia Grybauskaite ir krašto apsaugos ministras Raimundas Karoblis. Pasak R. Karoblio, anksčiau Rusija šių raketų kompleksų atveždavo pratyboms, tačiau „šị kartą situacija yra kita - tai yra nuolatinis dislokavimas, turint visą tam reikalingą infrastruktūrą ${ }^{" 26}$. Apie savo susirūpinimą pareiške ne tik lietuviai, bet ir kitos NATO šalys ir Aljanso vadovybè. Rusijos Valstybès Dūmos Gynybos komiteto pirmininkas Vladimiras Šamanovas tik pasišaipè, esą Kaliningrado sritis - „mūsų teisèta teritorija, ką norim, tą darom, skirtingai nuo jų (NATO), besikviečiančių amerikiečius ir kitus nedraugiškai mūsų atžvilgiu nusiteikusius žmones ${ }^{\text {“27. }}$. V. Šamanovas apeliavo i̇ vadinamąją saugumo dilemą, taip pat ir ị faktą, kad $2015 \mathrm{~m}$. Rusija pasitrauke iš Itprastinių karinių pajègų Europoje sutarties (CFE).

Minèta, jai rusai kruopščiai ruošèsi. Tai rodè nuolat tobulinama karinė parengtis strateginèse pratybose „Zapad“ (1999, 2009, 2013 ir 2017 m.). Nuosekliai vyko techninis karinių pajëgų, dislokuotų Kaliningrade, perginklavimas ${ }^{28}$. Pagaliau imtasi ir organizacinių priemonių, pakeičiant prieš keletą metų visą Rusijos Baltijos karinio jūrų laivyno vadovybę per vieną naktį. Atsižvelgiant í visas Rusijos karinių pajęgu vystymo priemones, taikytas Vakarų karinėje apygardoje, galima teigti, kad 2015-2016 m. Maskva ịgijo visišką konvencinès

\footnotetext{
${ }^{24}$ „JAV ir Europą nuvylè V. Putino kalba Miunchene“ (2007), delfi.lt, 2007- 02-12.

25 „Šalia Karaliaučiaus gali būti dislokuoti nauji Rusijos raketiniai kompleksai“ (2017), delfi.lt, 2017-12- 02.

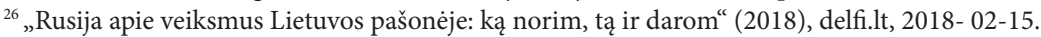

${ }^{27}$ „Rusija apie veiksmus Lietuvos pašonèje: ką norim, tą ir darom“ (26 išnaša).

${ }^{28}$ Ivanauskas V., Keršanskas V., Kasčiūnas L. (2016-2017), Kaliningrado veiksnys Lietuvos ir Rusijos santykiuose: reikšmė Lietuvos saugumui, Lietuvos metiné strategine apžvalga, t. 15, p. 131-157.
} 
ginkluotès pranašumą prieš NATO ${ }^{29}$. Kaliningrado sritis šiame procese suvaidino esminị vaidmenį.

Taip klostantis aplinkybėms galime išvysti ir strategiškai naują Kaliningrado srities perspektyvą. Kaliningradas tapo ne tik rusų A2/AD „burbulų“ centru, keliančiu saugumo iššǔkius Baltijos valstybėms ir Lenkijai, bet ir veiksniu, mažinančiu Baltarusijos strateginị geopolitinị vaidmenị. Akivaizdu, kad sparti Kaliningrado srities remilitarizacija mete iššūki ne tik regioninėms valstybėms, bet ir transatlantiniams santykiams, ką parodè trijų Baltijos valstybių prezidentų vizitas Vašingtone 2018 m. balandžio pradžioje.

Kaliningrado sritis iš tiesų tampa Rusijos kontroliuojama geopolitine sąsaja: eksklavas geopolitiškai susijęs su Rusija ir labai svarbus Rusijos strateginiuose santykiuose su Vakarais.

Beje, verta atkreipti demesị ị Kaliningrado remilitarizacijos sąsają su padètimi Kuriluose. Dar 2011 m. vasarą Prancūzijai ir Rusijai pasirašius sutartị, pagal kurią Paryžius įsipareigojo pastatyti du „Mistral“ klasès desantinius laivus Rusijos gynybos ministerijai, šios ministerijos viceministras Vladimiras Popovkinas pareiškè, kad Maskva vieną laivą skirs Kaliningrado, o kitą Kurilų apsaugai ${ }^{30}$. Rusijai okupavus Krymą, Paryžius „Mistral“ laivų Maskvai nepardave. Tačiau Kremlius idejos stiprinti karinius pajègumus Kuriluose neatsisakè.

2016 m. Rusija modernizavo salose karinę infrastruktūrą, ėmė didinti karini personalą. $2017 \mathrm{~m}$. pradžioje paskelbusi apie planus statyti karinę jūrų bazę, Maskva metų pabaigoje pradejo realius statybos darbus. $2018 \mathrm{~m}$. pradžioje Rusijos premjeras D. Medvedevas pripažino, kad Kuriluose dislokuojami kariniai lèktuvai ${ }^{31}$. Kilus regione susirūpinimui, V. Putinas pareiškè, kad Rusijos karinis aktyvumas Kuriluose susijęs su amerikiečių kariniu aktyvumu regione. Pasak V. Putino, tai ne Rusijos iniciatyva, o atsakas ị amerikiečių karinị aktyvumą Pietryčių Azijoje. Rusijos vadovas pripažino, kad nors su Japonija yra deramasi dèl bendrų projektų vystymo Kuriluose, Maskva nesiruošia atsi-

\footnotetext{
${ }^{29}$ Sukhankin S. (5 išnaša); Westerlund F. (2017), "Russia’s Military Strategy and Force Structure in Kaliningrad”, https://www.foi.se/download/18.bc6b81b15be852194d71d/1494413062692/RUFS\%20Briefing\%20 No\%2040\%20Kaliningrad\%20by\%20Fredrik\%20Westerlund.pdf, 2017-05-23.

30 “Can We Rule Out a New Pearl Harbour?”( 2011), https://orientalreview.org/2011/08/10/can-we-ruleout-a-new-pearl-harbour/ , 2017-12-06.

${ }^{31}$ Southgate L. (2018), „An old dispute re-emerges as Russia militarises Kuril Islands“, https://globalriskinsights.com/2018/03/japan-russia-dispute-northern-territories/, 2018-04-02; „Russia Starting Construction of Naval Base in Kuril Islands“ (2017) 1130 // http://www.navyrecognition.com/index.php/news/ defence-news/2017/november-2017-navy-naval-forces-defense-industry-technology-maritime-securityglobal-news/5761-russia-starting-construction-of-naval-base-in-kuril-islands.html, 2017-12-05; „Russia Approves Deployment of Warplanes to Kuril Islands“ (2018), https://themoscowtimes.com/news/russiaaproves-deployment-of-warplanes-in-kuril-islands-60381, 2018-02-03.
} 
sakyti salų. Jo nuomone, jei Rusija žengtų tokị žingsnį, salose išvystume ne tik japonus, bet ir amerikiečių kareivius. V. Putinas apeliavo ị japonų-amerikiečių Karinių pajègų statuso sutartị (SOFA), kuri tokią galimybę numato ${ }^{32}$. Taigi ir Kurilai traktuojami kaip prieš JAV nukreiptas geopolitinis įrankis, skirtas didinti Rusijos strateginę įtaką Tolimuosiuose Rytuose, Pietryčių Azijoje ir Ramiojo vandenyno baseine.

\section{Kitų valstybių ir tarptautinių institucijų veiksnys Kaliningrado problemoje}

Po Šaltojo karo pabaigos Kaliningrado problema domino nemažą skaičių Vakarų valstybių. Pažymètina, kad iš esmès visos jos nepriminė Rusijai komplikuotų teisinio ir politinio Kaliningrado srities statuso aspektų, vengè sukelti ịtarimus dèl separatinių tendencijų srities atžvilgiu eskalavimo. Nepriklausomai nuo tokios Vakarų laikysenos galimo paaiškinimo bandymais neatstumti, o vèliau struktūriškai pririšti Rusiją prie Vakarų, ši pozicija Maskvai atvėré manevravimo laisvę jègų balansavimui vakariniame flange, leido politinę-teisinę eksklavo problemą pakeisti „techniniais“ srities ekonominès ir socialinès plètros klausimais bei užsitikrinti, kad Vakarų valstybių, taip pat ir ES požiūris Kaliningrado srities atžvilgiu reikšis tik su Maskvos žinia. Pagaliau „drovus" Vakarų elgesys suteikè Rusijai, brěžiančiai tiesioginę geopolitinę liniją tarp Maskvos ir Kaliningrado, galimybių panaudoti ją kaip instrumentą (pavyzdžiui, reikalaujant specialių sprendimų dèl srities kaip Rusijos Federacijos sudedamosios dalies gyvybiškumo) stabdant Vakarų struktūrų plètrą ir integraciją, kitaip tariant, paverčiant eksklavą Rytų-Vakarų santykių įkaitu.

Tokią Kaliningrado geopolitikos formulę mėgino kvestionuoti kaimyninès (tarpinès) valstybès, Lietuva ir Lenkija, rodžiusios nemažą angažuotumą Kaliningrado srities padètimi ypač savųjų apsisprendimų dẻl gravitacijos ị Vakarus ir praktinio jų igyvendinimo laikotarpiais. Jos ne kartą bandè atkreipti Vakarų dėmesį į Rusijos užsienio politikos strategiją revizuoti euroatlantinès integracijos įtakoje besiklostantị jègų santykị remiantis didžiųjų valstybių koncerto modeliu ir skundèsi, kad tai bandoma padaryti tarpinių valstybių interesų sąskaita ir kad tam gali būti panaudota Kaliningrado srities problema.

\footnotetext{
32 Taishu Pitt J. (2017), „The Third Annual Eastern Economic Forum and the Japan-Russia Summit“, https://thediplomat.com/2017/09/the-third-annual-eastern-economic-forum-and-the-japan-russiasummit/, 201709 08; Gady F.-S. (2017), „Putin: Russian Force Buildup in Kuril Islands a Response to US Military Actions“, https://thediplomat.com/2017/06/putin-russian-force-buildup-in-kuril-islands-aresponse-to-us-military-actions/ 20170605.
} 
Lietuvai tai padejo susilaukti JAV ir Didžiosios Britanijos paramos atlaikant Rusijos spaudimą dèl karinio tranzito per jos teritoriją įteisinimo 19931995 ir 2001 m. Susilaukè Europos Komisijos ir kai kurių Šiaurès Europos valstybių pritarimo ir oficialaus Vilniaus $1998 \mathrm{~m}$. suformuluota situacija „Kaliningrado srities problemą paversti privalumu“. Pabrèžtina, kad šiai situacijai iš pradžių neprieštaravo ir Maskva, amžių sandūroje vertinusi Lietuvos narystę ES kaip tolimą perspektyvą ir daugiau rodžiusią rūpestị kalti pleištą tarp JAV ir Europos bei plèsti dvišalius santykius su didžiosiomis ES valstybėmis.

Tačiau palaipsniui suvokdama padariusi klaidą vertindama euroatlantinès integracijos mastą ir spartą, Maskva atvirai perejo prie konfliktinio balansavimo. Aiškindama, kad ES pletra Kaliningrado srities atžvilgiu yra išorinis įvykis, todèl atsakomybė už šio Rusijos Federacijos regiono adaptaciją ir susisiekimą su kontinentine Rusija tenka Briuseliui, ji siekè pakeisti dialogo dèl Kaliningrado srities raidos struktūrą, šalindama iš jo "tarpininkus“ ir derédamasi dèl eksklavo klausimų tiesiogiai su didžiosiomis ES valstybèmis ir Briuseliu.

Lenkija ir Latvija, siekdamos neutralizuoti rusiškojo veiksnio įtaką nacionaliniams euroatlantinès integracijos interesams, linko mažinti savo angažuotumą šiame dialoge. Pasiskelbusios „netranzitinèmis“ šalimis, jos iš esmès palengvino Rusijai susikoncentruoti tik ties vienu taikiniu - Lietuvos Respublikos teritorija.

Kompromituodama Vilnių kaip kliuvinį normaliai eksklavo raidai, Maskva reikalavo eksteritorinių koridorių bei kitokių preferencijų rusiškajam veiksniui Lietuvos teritorijoje. Tuo tarpu pasinaudodama dvišaliais santykiais su didžiosiomis ES valstybėmis, Rusija spaude ir atvirai šantažavo ir Europos Komisiją, siekdama gauti privilegijų bei kompensacijų visiems Rusijos Federacijos gyventojams, o po ES plètros pareikalavo specialaus derybinio formato Kaliningrado srities klausimams svarstyti.

Vakarų valstybės nedrịso priminti Rusijai, kad Kaliningrado srities statuso klausimas tarptautinès teisès požiūriu yra neišspręstas - teisès principu išsižadejjimas dèl tariamos naudos ir iš to kylantis nusilenkimas jẻgos principui. Buvo pasirinktas „lankstus“ sprendimas - politine problema iš pat pradžių buvo pakeista „techniniais“ srities ekonominès ir socialinès plètros klausimais. „Drovus“ Vakarų valstybių elgesys - nenoras priminti politinị ir teisinị srities statuso aspektus - baigèsi, kaip ir buvo galima laukti, ,jègos politika“ - Rusijos spaudimu ir net atviru šantažu.

Diplomatiniai Rusijos ir ES santykiai parodè, kad pirmoji formaliai prièmé antrosios siūlomas tų santykių taisykles ${ }^{33}$. Briuselis atsisakè prisiimti

\footnotetext{
${ }^{33}$ Lopata (6 išnaša), p. 107-115.
} 
politinę atsakomybę už srities raidą, sutiko orientuotis tik $\mathfrak{i}$ tas problemas, kurios kilo dèl tiesioginių procedūrinio pobūdžio ES plètros pasekmių, ir neatsisakè atverti europinius fondus ekonominiam eksklavo augimui faktiškai pagal Rusijos sąlygas.

Vis dèlto iš esmès naują Kaliningrado srities perspektyvą, neleidžiančią eksklavui nutolti nuo metropolijos ir projektuojančią jam aktyvios rusiškosios geopolitinės ịkamšos europinės integracijos erdveje funkciją, atvėre Maskvos tiesioginis strateginis kontaktas su Vakarais, konkrečiai su svarbiausiu šiame kontekste kontrahentu - Berlynu. Konkrečias šio kontakto apraiškas galima buvo išvysti ir anksčiau, ir dabar („Nord Stream“ I ir II). Kita vertus, tokiose ES žingsniuose galima įžvelgti ir bandymus „pririšti“ Rusiją prie Europos.

Po Krymo okupacijos padètis pasikeitè. Sankcijos Rusijai yra griežtinamos. Kaliningrado sritis ir joje dislokuotas karinis potencialas suvokiami kaip Rusijos priemonè dialogui su Vakarais dèl galios pusiausvyros palaikymo ${ }^{34}$. Tačiau nereikètų atmesti galimybės, kad Kaliningradas, pasikeitus tarptautinėms aplinkybèms, vèl gali tapti „pereinamuoju pèstininku“ Rusijos -Vakaru geopolitinejje šachmatų partijoje. Maskvą persvarstyti savo politiką paskatintų derybos su ES dèl bevizio režimo (Kaliningradui tampant šio proceso „bandomuoju regionu") ar dèl ES - Eurazijos ekonominès sąjungos derybos dèl laisvos prekybos erdvès „nuo Lisabonos iki Vladivostoko“.

Taip pat pastebetina, kad nepaisant sankcijuc ir, atrodo, nepalankios socialinès-ekonominès aplinkos, Kaliningrade neatsisako investuoti vokiečiai („BMW“), o ir lietuviai (trąšos).

\section{Eksklavo jungties su metropolija užtikrinimas (karinio, keleivių ir krovinių tranzito klausimai)}

Siekdama išvengti eksklavo izoliacijos nuo kontinentinès Rusijos teritorijos, užsitikrinti papildomus saugiklius srities priklausomybei laiduoti bei itakai integraciniams procesams ES didinti, Rusija naudojo ir kitus būdus. Manipuliuodama eksklavo kaip „bandomojo regiono“ idèja, ji èmési stiprinti centro kontrolès sričiai mechanizmus.

Turint omenyje tai, kad po Šaltojo karo daugelis prognozių Kaliningrado srities atžvilgiu neišsipildè, o pačių rusų ịvairūs srities modernizavimo planai dèl ịvairių priežasčių nebuvo iggyvendinti, tikètina, kad Maskva, didin-

${ }^{34}$ Westerlund F. (29 išnaša). 
dama srities priklausomybę, daugiau kliausis tradicinemis tos priklausomybès užtikrinimo priemonèmis - stiprindama eksklavo jungtị su metropolija.

Tradiciškai šią jungti Rusija siekè užtikrinti per Lietuvos teritoriją, išnaudodama tranzito - karinio, keleivių, krovinių - klausimus.

Rusiškojo karinio tranzito ị / iš Kaliningrado srities per Lietuvos teritoriją klausimas buvo pats jautriausias, kèlęs tarp Maskvos ir Vilniaus nemažą įtampą. Problemos esmè ta, kad Rusija savo kariniam tranzitui per Lietuvos teritoriją siekẻ specifinių sąlygų - bandè legitimizuoti šs tranzitą, faktiškai suteikdama jam setlementinị statusą. Tuo tarpu Lietuva šiose Rusijos užsienio politikos pastangose įžvelgè pavojų savo suverenitetui ir integracijai ị NATO. Šiuo klausimu buvo pasiektas kompromisas, kuris, neatimdamas iš Maskvos galimybių naudotis tranzitine teritorija, išsaugojo Lietuvos suverenumą ${ }^{35}$. Nusistovejjusi rusiškojo karinio tranzito tvarka nesutrukdè Lietuvai integruotis ị euroatlantines struktūras. Tačiau tai nereiškia, kad Maskva nebando šios tvarkos kvestionuoti ir gali imtis provokacijų, paaštrèjus, pavyzdžiui, santykiams su atskiromis euroatlantinei erdvei priklausančiomis valstybėmis ir institucijomis.

Rusijos Federacijos piliečių tranzito $\mathfrak{i}$ / iš Kaliningrado srities tranzito klausimas taip pat išspręstas kompromisu. Tiesa, sprendžiant klausimą dalyvavo ne tik Lietuva ir Rusija, bet ir ES. Bent šiuo metu šis rusų keleivių tranzitas per Lietuvos teritoriją grèsmių nekelia, yra kontroliuojamas. Tačiau tai nereiškia, kad Maskva neatsisakytų išnaudoti šį tranzitą kaip provokacijų ịrankį.

Nepaisant Rusijos pastangų specifiškai institucionalizuoti krovinių tranzito í / iš Kaliningrado srities klausimą, sprendimai dèl šios rūšies rusiškojo tranzito rutuliojasi techninio pobūdžio lygmeniu ir dažnai priklauso nuo santykių tarp ES ir Rusijos pobūdžio.

Šiuo metu vienas iš Maskvos galvosūkių - srities aprūpinimas energetiniais ištekliais. Po to, kai Baltijos šalys desinchronizuosis nuo vadinamojo BRELL žiedo, Kaliningrado regionas taip pat nebepriklausys šiai energetikos sistemai ir turès veikti savarankiškai. Naujų termofikacinių jègainių atidarymas srityje $2018 \mathrm{~m}$. pradžioje parode, kad Maskva tam rimtai ruošiasi. Atidarymo ceremonijoje „Inter RAO“ valdybos pirmininkas pareiške, kad jègainès skirtos „užtikrinti patikimą elektros tiekimą Kaliningrado energe-

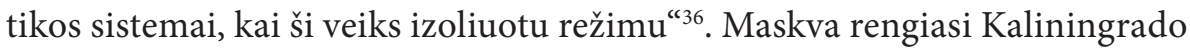
energetikos sistemą išlaikyti izoliuotą.

Tai rodo energetiniai planai, kuriuose ne tik dar kelių šiluminių elektri-

\footnotetext{
${ }^{35}$ Laurinavičius Č., Lopata R., Sirutavičius V. (22 išnaša), p. 30-35.

${ }^{36}$ „Energetikos ministras: Rusija ruošiasi Baltijos šalių elektros tinklų atjungimui“ (2018), delfi.lt, 2018 m. kovo $3 \mathrm{~d}$.
} 
nių, bet ir suskystintųjų dujų terminalo statybos, taip pat naftos Baltijos jūroje plètra. „Lukoil“ skelbiasi šiais metais pradèsiantis statyti dar vieną platformą (D41) ir planuoja naujus naftos gręžinius prie Kuršių nerijos (D18 ir D19). Panašu, kad šie planai ir atsispindejjo minètame naujajame V. Putino pasirašytame įstatyme dẻl Kaliningrado srities ekonominio-socialinio vystymo. İstatymu, be kita ko, praplečiama SEZ teritorija, įtraukiant $\mathfrak{i}$ ją Kaliningrado srities vidaus vandenis ir Rusijai priklausančią Baltijos jūros dalis. Maskva nepamiršta ir „Nord-Stream II“ projekto bei planuojamos „dujinès“ atšakos ị sritị.

Grižtant prie tranzito, svarbu pabrèžti, jog metropolija deda nemažai pastangų visas tris tranzito rūšis susieti. Tokiu būdu ji bando specifinị keleivių tranzito režimą pradèti taikyti ir krovinių vežimams, o eventualiai - ir kariniam tranzitui $\underset{i}{\mathfrak{l}}$ / iš Kaliningrado srities per Lietuvos teritoriją. Kita vertus, minèti energetiniai projektai, taip pat ir kiti projektai, pavyzdžiui, susiję su transporto infrastruktūra (greitkelių statyba ir rekonstrukcija, oro uosto „Chrabrovas“ rekonstrukcija ir plètra, tarptautinès kruizinių laivų ir krovinių jūros terminalo Pionerske statyba, esamo Kaliningrado uosto infrastruktūros modernizavimas, naujų keltų linijai Kaliningradas-Ustluga statyba) rodo, kad Maskva dès visas pastangas palaikyti Kaliningrado srities gyvybingumą izoliacijos ir tranzito varžymo (nutraukimo) sąlygomis.

\section{Išvados}

Apibendrinant, reikia pabrèžti, kad Maskva po Šaltojo karo nuolat palaikè ịtampą dèl dviejų jos strategijų Kaliningrado srities („zagraničnaja Rosija“) atžvilgiu. Pirmoji - srities, kaip karinio forposto, ypatingo strateginio regiono, atsižvelgiant ị aplinkybes atliekančio placdarmo ịtakai plèsti ir (arba) barjero Vakarų ịtakai stabdyti vaidmeni. Antroji - srities, kaip ekonominių reformų bandymų aikštelès, galejjusios dèl savo palankios geografinès padèties tapti geopolitine sąsaja, jungiančia Rusiją su Vakarais.

Tam tikrais laikotarpiais būta gana pagrịstų vilčių, kad Maskvoje palaipsniui įsivyraus KS kaip ekonominių reformų bandymų aikštelès vizija. Ji netgi diplomatiniuose dokumentuose, derintuose tarp Vakaru ir Rusijos, buvo vadinta „bandomuoju projektu“, o ir pati Maskva nesibodejo teikti sričiai vilčių kaip kompensaciją už ekslaviškumą gauti naują politinį ir ypatingą ekonominị statusą. Tiesa, šiandien akivaizdu, kad tuo metu Maskva faktiškai neturèjo strateginio plano, kaip užtikrinti stabilią socialinę-ekonominę srities raidą, ir ne iš karto suvoke tarptautinių procesų, pirmiausia - eurotlan- 
tinès integracijos - masto ir spartos. Kadangi strateginès vizijos dèl KS neturèjo ir Vakarai, Maskvai atsivèrè manevravimo laisvé galios balansavimui vadinamajame vakariniame flange, leido politinę eksklavo problemą pakeisti „techniniais“ srities ekonominès-socialinès plètros klausimais ir užsitikrinti, kad Vakarų valstybių požiūris ES atžvilgiu gali reikštis tik su Rusijos žinia. Tokiu būdu Kremlius suvokè, kaip euroatlantiniais integracijos procesais galima pasinaudoti.

Maždaug prieš penkiolika metų Maskvoje apsispręsta, kad dramatiškas ekonominis srities atsilikimas nuo kaimynų, visų pirma, Lenkijos ir Lietuvos, gali būti pragaištingas. Todèl bandyta ieškoti naujų instrumentų ir naujų veikimo erdvių. Mestos federalinès lěšos „stabilizuoti“ ekonominį atotrūkį nuo kaimynų, paskelbtas šūkis, esą Kaliningradas yra Rusijos langas ị Europą, t. y. sritis turi būti ne teritorija, kurią europiečiai stengiasi išnaudoti kaip lengvatinę kortą skverbiantis ị Rusijos rinkas, o placdarmu rusiškajam verslui integruotis $\mathfrak{i}$ europines rinkas, bandyta modernizuoti srities valdymą, apsispręsta netgi sulaužyti tradiciją traktuoti Kaliningrado istoriją tik nuo $1945 \mathrm{~m}$. ir pripažinti istorijos tęstinumą, taip pat mielai sutikta ES finansine parama, žinoma, ją perskirstant Maskvoje.

Taigi realioje diplomatineje praktikoje Kaliningrado sritis virto ịkeistu daiktu, naudojamu Rusijos ir Vakarų strateginiuose mainuose, paremtuose atgrasinimo (sulaikymo) - nuraminimo ir susiejamumo taktika. Iki $2004 \mathrm{~m}$. Kaliningrado sritis buvo paversta geopolitiniu ikaitu - cesijos procese karo grobio pagrindu atitekusi teritorija, kuria siekta ne tik išlaikyti, bet ir priversti kitas šalis, tarptautines institucijas susilaikyti nuo bet kokio tiesioginio arba netiesioginio ịkaito išlaisvinimo akto. Kartu tai reiške, kad eksklavo, kaip geopolitinio ịkaito, transformacijos kryptis priklausys ir nuo to, ar Rusijos politika srities atžvilgiu sudarys sąlygas federaliniam centrui eksklavą panaudoti kaip placdarmą savo įtakos ES didinimui labiau, nei didès Kaliningrado srities atsiverimas ES.

Pabrèžtina, kad Kaliningrado srities ateities klausimą Maskva sieja ne tik su Potsdamo šleifo ịveika santykiuose su Vakarais, bet ir su Kurilų priklausomybės klausimo byla santykiuose su Japonija ir šios bylos ịtaka Rusijos strategijai Tolimuosiuose Rytuose. Rusija suvokè, kad absoliutus teritorinis legitimumas yra nepasiekiamas tiek Kuriluose, tiek - galbūt mažesniu laipsniu - Kaliningrade. Maskva tikejosi ir tebesitiki spręsti šią problemą palankaus sau balanso sukūrimu: rytinių sienų legitimumo kvestionavimą iš Japonijos (JAV) pusès ji bandè atsverti Kinijos, o Kaliningrado priklausomybę - Vakaru Europos valstybių kortomis. Tokiu balansavimu Kremlius vylèsi ne tik išlaiky- 
ti status quo vakariniame ir rytiniame flanguose, bet ir neuždaryti kelio savo eventualiems politiniams, diplomatiniams, įtakos sferų, neatmetant teritorinių, laimèjimams.

Po Vakarų plètros Vidurio-Rytų Europoje akademinis dėmesys Rusijos balansavimui, naudojant Kaliningrado veiksni, nuslopo. Tačiau po Rusijos karinès intervencijos $\mathfrak{i}$ Ukrainą prasidejusi galios pusiausvyros slinktis Baltijos jūros regione verčia iš naujo permąstyti Kaliningrado politinị, ekonominị ir karinį statusą, jo vietą naujoje saugumo architektūroje.

Maskva sugriežtino socialinių-ekonominių ir politinių procesų Kaliningrado srityje kontrolę. Metropolija finansinėmis subsidijomis, ekonominio statuso keitimais, infrastruktūriniais projektais mėgina stabilizuoti socialinę-ekonominę padètį eksklave ir deda visas pastangas palaikyti Kaliningrado srities gyvybingumą izoliacijos ir tranzito varžymo (nutraukimo) sąlygomis. Politinè kontrolè užtikrinama Maskvos tiesioginiais statytiniais srities vadovybèje ir „Vieningosios Rusijos“ dominavimu vadinamosiose renkamose institucijose.

Po karo prieš Gruziją, maždaug nuo 2009 m., Rusija èmėsi rimtų organizacinių ir karinių pajegų telkimo priemonių. Jos palietè ir Kaliningrado sriț, kuri jau iki $2016 \mathrm{~m}$. virto grėsmingu kariniu bastionu. Atsižvelgiant ị visas Rusijos karinių pajėgų vystymo priemones, taikytas Vakarų karinèje apygardoje, galima teigti, kad 2015-2016 m. Maskva igijo visišką konvencinès ginkluotès pranašumą prieš NATO. Kaliningrado sritis šiame procese suvaidino esmini vaidmenị.

Taip klostantis aplinkybėms galime išvysti ir strategiškai naują Kaliningrado srities perspektyvą. Kaliningradas tapo ne tik rusų A2/AD „burbulų“ centru, keliančiu saugumo iššūkius Baltijos valstybėms ir Lenkijai, bet ir veiksniu, mažinančiu Baltarusijos geopolitinị vaidmenị. Akivaizdu, kad nuosekli Kaliningrado srities remilitarizacija metė iššǔki ne tik regioninėms valstybèms, bet ir transatlantinèms santykiams. Maskvai eksklavo karinis potencialas yra priemonè strateginiam dialogui su Vakarais dèl jegų balanso palaikymo. Pastebètina, kad ir remilitarizuojamų Kurilų veiksnị Maskva traktuoja kaip prieš JAV nukreiptą geopolitinị ịrankị, skirtą didinti Rusijos strateginę itaką Tolimuosiuose Rytuose, Pietryčių Azijoje ir Ramiojo vandenyno baseine.

Tačiau nereikètų atmesti galimybès, kad Kaliningradas, pasikeitus tarptautinèms aplinkybèms, vèl gali tapti „pereinamuoju pėstininku“ Vakarų-Rusijos geopolitinejje šachmatų partijoje. Maskvą persvarstyti savo politiką Kaliningrado atžvilgiu paskatintų derybos su ES dèl bevizio režimo 
(Kaliningradui tampant šio proceso „bandomuoju regionu“), ES - Eurazijos ekonominès sąungos derybos dèl laisvos prekybos erdvès „nuo Lisabonos iki Vladivostoko“ (galimas daiktas, Kurilų funkcija priklausytų nuo augančio Rusijos poreikio mažinti priklausomybę nuo Kinijos, pasitelkiant kaip atsvarą Japoniją) ir kt. veiksniai.

2018 balandis 